\title{
Doing Business As
}

National Cancer Institute

\section{Source}

National Cancer Institute. Doing Business As. NCI Thesaurus. Code C117113.

A legal term meaning that the trade name, or fictitious business name, under which the business or operation is conducted and presented to the world is not the legal name of the legal person(s) who actually owns the business and is responsible for it. 